This is the final author version of an article that was published as

Walczak, A., \& Fryer, L. (2017). Creative description: The impact of audio description style on presence in visually impaired audiences. British Journal of Visual Impairment, 35(1), 6-17.

Creative description: the impact of audio description style on presence in visually impaired audiences in

\title{
Agnieszka Walczak
}

Department of Translation and Interpretation, Universitat Autònoma de Barcelona, Barcelona, Spain

\section{Louise Fryer}

Centre for Translation Studies, University College London, London, United Kingdom

\section{Abstract}

This paper presents a study that tested the impact of audio description (AD) style on dimensions of presence (spatial presence, ecological validity, engagement and negative effects) in blind and visually impaired audiences. The participants were shown two fragments of a naturalistic drama with two styles of description: 'standard' and 'creative'. While the former followed the principle of objectivity, the latter was an innovative type of AD that included elements of camera work and subjective descriptions of the characters, their actions and scenes crucial to the plot. The findings show that the emotive AD prompted higher levels of presence for all 
participants. Overall, the new AD style seemed more natural, especially to participants with recent sight loss. The results suggest that creative scripts may stimulate presence, and thus increase the chances of AD users having a more immersive viewing experience.

\section{Keywords}

Audio description, creative description, presence, blind and visually impaired, audiovisual translation, accessibility

\section{Introduction}

By 'translating visual images into verbal descriptions' (Braun, 2008, p. 14), audio description (AD) makes audiovisual content accessible to everyone, especially people who are blind or visually impaired (B/VIP). The success of AD 'depends on how the transposition of visual material into words is handled' (Taylor, 2014, p. 42). Existing codes of good practice suggest that the wording of descriptions should be 'as impartial as possible' and discourage the use of technical terms, such as camera angles (Rai, Greening, \& Leen, 2010, p. 8). Recent studies have shown, however, that audiences respond positively to alternative versions of $\mathrm{AD}$.

Fels, Udo, Ting, J. E. Diamond and J. I. Diamond (2006) compared the reactions of 
$\mathrm{B} / \mathrm{VIP}$ users to both conventional third-person $\mathrm{AD}$ and unconventional first-person $\mathrm{AD}$ styles in an animated situation comedy Odd Job Jack (2004. dir. Adrian Carter and Denny Silverthorne Jr.), produced by Smiley Guy Studios in Canada. Their findings showed that the participants enjoyed the first-person AD style most. Although they said that it made their experience with the show less trustworthy, in the end they assessed it as more engaging and entertaining than the third-person AD.

Another alternative AD using subjective, emotional vocabulary was prepared for a live production of Hamlet (Udo \& Fels, 2009; Udo, Acevedo, \& Fels, 2010). It focused on recreating the feel of the scene. Theatrical conventions as well as non-traditional theatrical mediums were used to deliver the complex vision of the director. The AD was written in a traditional Shakespearian form - iambic pentameter - and delivered from Horatio's point of view. The reaction of the B/VIP audience was positive. They found the new AD style enjoyable and entertaining.

Fryer and Freeman (2012a) prepared AD in two different styles to a fragment of Brief Encounter (1945, dir. David Lean) and tested it with B/VIP users. One AD script was conventional and followed the Ofcom guidelines promoting the description of 'characters, locations, time and circumstances, any sounds that are not readily identifiable, on-screen action, and on-screen information' (Ofcom, 2008, point A4.25). 
The other AD script was called 'cinematic'. It intentionally contradicted the Ofcom guidelines by incorporating specific film terminology. The feedback received after the screening was favourable, with almost $70 \%$ of B/VIP users expressing a preference for the 'cinematic' AD.

Similarly, Szarkowska (2013) advocated a new AD style called 'auteur description' as a solution to describe artistic cinema for B/VIP audiences. The novelty of this approach was that the AD script relied closely on the screenplay of the film. The resulting description was abundant with metaphors, neologisms and descriptions of emotions. The new AD style was tested with B/VIP users during a screening of Volver (2006, dir. Pedro Almodóvar). Their opinions, in the great majority, were positive. They found the ‘juicy and vivid descriptions' entertaining and helpful in following the plot (2013, p. 386).

This paper follows previous investigations, but takes the analysis one step further. It chooses a new film genre which has not yet been analysed before in scientific research on AD - a naturalistic drama (Styan, 2002) - that aims at reproducing the reality as faithfully as possible, focuses on ordinary people in their natural setting, and shows the dark side of human existence. The paper also presents an alternative approach to standard AD style called creative description (CRD). Drawing on the concept of 
'autodescription' posited by Künstler (2010), the CRD includes elements of film terminology and subjective descriptions of the main elements of AD: characters, actions and scenes. The resulting AD may therefore be viewed as a combination of 'cinematic description' introduced by Fryer and Freeman (2012a) and 'auteur description' proposed by Szarkowska (2013). Our hypothesis was that the CRD would have a direct effect on the reception of the film, giving B/VIP audiences the chance of a more engaging experience.

What follows is a brief summary of the research on the emotional reception of AD. A detailed description of the methodology is subsequently presented, including the differences between the standard and creative AD styles. After this, the results of the study are reported and, finally, conclusions and suggestions for possible further research are forwarded as a way of drawing the paper to a close.

\section{Emotional reception of $\mathrm{AD}$}

Early research into AD reception focused on user comprehension (Chmiel \& Mazur, 2012; Romero-Fresco \& Fryer, 2013; Schmeidler \& Kirchner, 2001; Walczak \& Rubaj, 2014) rather than on the impact $\mathrm{AD}$ may have on the quality of experience of $\mathrm{AD}$ audiences. Until now, only a few scholars have addressed this issue. 
Ramos Caro and Rojo López (2014) have studied the influence of AD on the emotional response of sighted and B/VIP users watching mainstream and avant-garde films. The AD under analysis in their research followed the principle of objectivity. The results showed statistically significant differences in emotional responses to the avant-garde film between the two groups, suggesting that the existing guidelines on $\mathrm{AD}$ creation need to be revised as avant-garde films may require a less detached approach to AD compared to mainstream productions. A further piece of research, conducted by Ramos (2015), analysed the emotional experience of sighted and B/VIP users when presented with three different stimuli: scenes with images and sound, scenes with sound only, scenes with $\mathrm{AD}$. The author demonstrated that $\mathrm{AD}$ had the potential of triggering an intense emotional reaction in both sighted and B/VIP audiences. She also suggested that the necessity to describe the images for B/VIP audiences depends on the nature of the scenes: their visual aspects and the emotions they convey. In her latest research, Ramos Caro (2016) has concentrated on the emotional impact of language in AD. The aim of her study was to determine whether there are any differences in the emotional reactions of sighted and B/VIP participants to materials with two different versions of AD: neutral and emotional. The results showed that the emotional version of AD elicited a stronger emotional response in both user groups. This suggests that the language used in AD should be carefully selected, especially in those scenes that rely closely on audio 
information. In all the above mentioned studies, the instruments used to measure the responses of participants included a self-report questionnaire with items describing emotional states, heart rate measurement or a retrospective questionnaire.

In their research, Fryer and Freeman (2012b, 2013, 2014), on the other hand, focused on the concept of presence. Defined as the 'suspension of disbelief' (Slater \& Usoh, 1993, p. 222) or 'perceptual illusion of non-mediation' (Lombard \& Ditton, 1997, p. 9), presence is a subjective experience of being in one environment, while physically situated in another. It allows for direct comparison of experiences of users with a variety of sight conditions, including persons with visual disabilities. In one of their studies, Fryer and Freeman (2012b) compared the presence levels of sighted and B/VIP users watching the same clip in three different versions: no $\mathrm{AD}$, 'standard' $\mathrm{AD}$, and 'cinematic' AD including film terminology. The study showed an interaction between AD style, sight and presence. Higher levels of presence were reported by B/VIP people watching the clip with $\mathrm{AD}$ than by sighted people watching it with no AD. Similarly to Ramos Caro and Rojo López (2014), the authors signalled the necessity to revisit the current $\mathrm{AD}$ guidelines as the 'cinematic' $\mathrm{AD}$ turned out to be highly engaging for the B/VIP users. In another study, Fryer and Freeman (2013) explored the impact of verbal pictures and sound effects on the dimensions of presence in sighted and B/VIP audiences. They observed that AD can influence the dimensions of presence in different 
ways and, furthermore, that the levels of presence for B/VIP users may exceed those of the sighted viewers when a stimulus is delivered with the appropriate AD style. Fryer and Freeman (2014) also tested the impact AD has on presence levels when delivered with a human or synthetic voice. The study was conducted with B/VIP users and the main conclusion was that only human voice $\mathrm{AD}$ can prompt higher levels of presence and enhance emotion elicitation. All these studies showed the potential of presence as a tool for measuring the effectiveness of AD. This test aims to verify that.

\section{Methodology}

This section describes the participants involved in the study, the questionnaire prepared, the stimulus used, and the procedure followed. All participants gave written consent. Ethical approval for the study was given by the Universitat Autònoma de Barcelona, Spain.

\section{Participants}

Thirty-seven volunteers from Poland took part. One participant was excluded for being under 18 years old, leaving the following sample: 36 participants (15 men and 21 women), aged 21-69 years $(M=35.5 ; S D=12.36)$, all with impaired vision. 
Participants were recruited through Polish foundations and organisations that support people with sight loss, e.g. the Polish Association of the Blind and the Vega Foundation for the Blind and Visually Impaired, and through personal contacts. All of them were officially registered as visually impaired and stated the age at which their registration took place. The majority had obtained their disability degree certification at the age of 16 or $18(72 \%)$, six people in their twenties $(17 \%)$, three in their thirties $(8 \%)$ and one person at the age of 50. The participants were asked to identify themselves as having mild (6\%), considerable (33\%) or complete $(61 \%)$ sight loss (see Table 1$)$. They also stated whether the sight loss was congenital (67\%) or acquired (33\%) and reported the name of their eye condition. Among people with congenital sight loss, retinitis pigmentosa, retinopathy of prematurity, cataract and glaucoma were most often mentioned as the cause of visual impairment. People with acquired sight loss primarily reported retinal detachment and retinopathy of prematurity.

Table 1. Participants' distribution based on age registered as B/VIP and sight loss.

\begin{tabular}{lllll}
\hline & \multicolumn{4}{c}{ Sight loss } \\
\cline { 2 - 5 } Age registered as B/VIP & Mild & Considerable & Complete & Total \\
\hline 16 or 18 & 1 & 8 & 17 & $26(72 \%)$ \\
$20+$ & 1 & 2 & 3 & $6(17 \%)$ \\
$30+$ & 0 & 2 & 1 & $3(8 \%)$ \\
50 & 0 & 0 & 1 & $1(3 \%)$ \\
\hline TOTAL & $2(6 \%)$ & $12(33 \%)$ & $22(61 \%)$ & 36 \\
\hline
\end{tabular}


To determine the visual acuity of participants more precisely, specific questions taken from the Network 1000 study (Douglas, Corcoran, \& Pavey, 2006) were asked. They concerned light perception, the ability to recognize friends and to read. The scale is included in Appendix 1. Two participants with mild sight loss reported they could see the shapes of furniture in the room and read a newspaper headline. One person reported they would be able to recognise a friend if they were at arms' length away. All participants with considerable sight loss, except for two, said they could see the shapes of furniture in the room. One person would be able to recognize a friend if they were close to her face, five if they were arms' length away, and two if they were on the other side of the room. Six participants confirmed they were able to read a newspaper headline, and one a large print book. Fifteen of those participants who reported to have complete sight loss declared they had no light perception, the remaining seven said they would be able to tell by the light where the windows were.

\section{Measures}

The demographic details, reported above, comprised gender, age, self-reported sight loss (mild, considerable, complete), visual acuity specification, age when registered as visually impaired, and the medical name of sight condition. Participants also stated their preference for the gender of voice to deliver $\mathrm{AD}$ and rated their familiarity with $\mathrm{AD}$, using a 5-point Likert scale ( $1=$ strongly disagree, $5=$ strongly agree) to respond to the 
statement 'I am familiar with AD'.

In order to judge the participants' emotional experience, the Elicited Emotion Scale (Gross \& Levenson, 1995) was used. On a scale from 1 to 5, participants rated the greatest amount of a given emotion experienced at any time during the clip $(0=$ 'not feeling even the slightest bit of emotion'; $5=$ 'the most you have ever felt in your life'). Of the original 16 items, two relevant to this study were chosen: Interest and Confusion. The participants' immersion in the presented material was measured with the ITC-Sense of Presence Inventory (Lessiter, Freeman, Keogh, \& Davidoff, 2001). It uses a 5-point Likert scale ( $1=$ strongly disagree; $5=$ strongly agree) to assess four dimensions of presence: sense of physical space, engagement, ecological validity and negative effects. To avoid fatigue, it was presented in the short form as in various other studies (e.g. Fryer \& Freeman, 2014; Hammick \& Lee, 2013). Three items were taken from each of the positive subscales: sense of physical space ('I felt I was visiting the places in the scenes'; 'I had a sense of being in the scenes'; 'I felt surrounded by the scenes'), engagement ('I felt myself being drawn in'; 'I lost track of time'; 'I paid more attention to the scenes than to my own thoughts') and ecological validity ('the scenes seemed natural'; 'the content seemed believable to me'; 'I felt the environments were part of the real world'). A single question dealt with negative effects: 'I experienced sensations 
such as dizziness, disorientation, nausea, a headache, or tiredness'. For the purposes of this study, one item - 'eye strain' - was removed from the negative sensations list. At the end, participants had to declare, using a 5-point Likert scale (1=strongly agree; $5=$ strongly disagree), whether they would like to watch the whole film with the given AD style.

Before the end of the test, participants had to state whether they had previously watched the film; if yes, if it was with or without AD. Finally, they were asked which AD version they preferred. There was also the opportunity to provide comments. All participants had the measures read aloud and dictated their responses.

\section{Stimulus}

Two clips from The Mighty Angel (2014, dir. Wojciech Smarzowski), lasting approximately $12 \mathrm{~min}$ each, were chosen for the study. Each clip presents two stories of people struggling with alcoholism and makes narrative sense as a stand-alone piece. Clip 1 is about two addicted women, Joanna and Mania, whereas clip 2 shows how Terrorysta and Jerzy, the main protagonist, are fighting against their alcoholic problems. 
Two AD scripts were created. One with a 'standard' description (STAD), following the 'what you see is what you say' (WYSIWYS) principle (Snyder, 2008); the other with a creative description (CRD) that included elements of camerawork and emotive language. The AD scripts were written by the first author, a professional audio describer, in consultation with an $\mathrm{AD}$ target user. The two AD styles were comparable in terms of text density, with 210 words of STAD vs 216 words of CRD for clip 1, and 215 words of STAD vs 224 words of CRD for clip 2. The AD was recorded in a professional studio and mixed with the film. A male Polish actor was chosen to read the text to match the dark atmosphere of the film and suit the tone of personal confessions of characters damaged by the addiction. Both texts were read with neutral intonation.

The main difference between the scripts lay in describing characters, their actions and scenes crucial to the plot. While the STAD opted for neutral, unmarked wording, the CRD deliberately incorporated colourful expressions and intensified vocabulary, making the text more credible and in line with the visual image. Table 2 shows fragments from two AD scripts side by side. The English translation of the examples is also provided.

Table 2. Extracts from the AD script for The Mighty Angel, showing standard and creative AD. 


\begin{tabular}{|c|c|c|}
\hline & Standard AD & Creative AD \\
\hline \multirow[t]{3}{*}{ Characters } & pijany [drunk] & dziabnięty [tipsy] \\
\hline & pijak [drunkard] & naprany [shitfaced] \\
\hline & podpity [a bit drunk] & nawalony [hammered] \\
\hline \multirow[t]{3}{*}{ Actions } & $\begin{array}{l}\text { Joanna pije z butelki. } \\
\text { [Joanna drinks straight from } \\
\text { the bottle] }\end{array}$ & $\begin{array}{l}\text { Joanna pije } \mathrm{z} \text { gwinta. } \\
\text { [Joanna takes a swig straight } \\
\text { from the bottle] }\end{array}$ \\
\hline & $\begin{array}{l}\text { Jerzy sika do szafy. } \\
\text { [Jerzy urinates into the closet.] }\end{array}$ & $\begin{array}{l}\text { Jerzy odlewa się do szafy. } \\
\text { [Jerzy pisses into the closet.] }\end{array}$ \\
\hline & $\begin{array}{l}\text { Jerzy wymiotuje na podłogę. } \\
\text { [Jerzy vomits onto the floor.] }\end{array}$ & $\begin{array}{l}\text { Jerzy puszcza pawia na podłogę. } \\
\text { [Jerzy pukes on the floor.] }\end{array}$ \\
\hline \multirow[t]{3}{*}{ Scenes } & $\begin{array}{l}\text { Przy biurku szef uprawia seks } \\
\mathrm{z} \text { jakąś kobietą. } \\
\text { [Standing by his desk, the boss } \\
\text { is having sex with some } \\
\text { woman.] }\end{array}$ & $\begin{array}{l}\text { Szef posuwa przy biurku jakąs } \\
\text { cizię. } \\
\text { [Standing by his desk, the boss } \\
\text { is banging some bird.] }\end{array}$ \\
\hline & $\begin{array}{l}\text { Joanna budzi się, jest ledwo } \\
\text { przytomna. Ma bieliznę } \\
\text { umazaną odchodami. } \\
\text { [Joanna wakes up, she is } \\
\text { barely conscious. Her } \\
\text { underwear is smeared in } \\
\text { excrement.] }\end{array}$ & $\begin{array}{l}\text { Joanna budzi się posrana, } \\
\text { poszczana i zarzygana. Nic nie } \\
\text { skleja. Zero kontaktu. } \\
\text { [Joanna wakes up smeared in } \\
\text { shit, piss and vomit. She can't } \\
\text { connect.] }\end{array}$ \\
\hline & $\begin{array}{l}\text { W pokoju bałagan, na łóżku } \\
\text { Jerzy w wymiocinach. } \\
\text { [There is a mess in the room. } \\
\text { Jerzy is lying on the bed } \\
\text { covered in vomit.] }\end{array}$ & $\begin{array}{l}\text { Krajobraz po bitwie. W pokoju } \\
\text { gigantyczny chlew, a na łóżku } \\
\text { charczące, zapite i zarzygane } \\
\text { ścierwo Jerzego. } \\
\text { [The room is a pigsty. Jerzy is } \\
\text { lying on the bed like a wheezing } \\
\text { sack, drunk and covered in } \\
\text { puke.] }\end{array}$ \\
\hline
\end{tabular}


Given that the film deals with alcohol abuse, its editing appears to be chaotic in order to mirror the nature of addiction. The pace of the storyline is dynamic and temporal continuity is not preserved. Rather the action jumps backward and forward and it is interspersed with digressions, hallucinations and philosophical reflections. Since at times it was crucial to highlight the camera's point of view to Smarzowski's audience, film terminology was not avoided in the CRD script. Due to time constraints, other elements within the script were repositioned or rephrased to add an extra layer of information about camerawork. This included such phrases as: 'a series of shots' or 'passages' that emphasized how repetitive the life of an addict is, 'to camera' or 'in front of the camera' to indicate when the characters were directly talking to the camera, 'the camera spinning around' to present the world from a character's 'drunk' perspective, 'a crane shot' to highlight the internal dilemma of a character or 'view from a CCTV camera' to signal a shot from a different perspective (for more examples see Walczak, in press).

\section{Procedure}

Each participant watched both clips, one in each AD style, on a laptop, without headphones. The viewing order and AD style was counterbalanced across the sample. As the visual rhythm of the clips was quite dynamic, with fast cuts, flashbacks and other 
cinematic techniques used to create a shifting range of perspectives, a short audio introduction, lasting around 30s, was played before watching the clips. Although not particularly common in ADs for films yet (cf. Fryer \& Romero-Fresco, 2014; RomeroFresco \& Fryer, 2013; Szarkowska \& Jankowska, 2015), the introduction was added to give the viewers a hint as to how the story is constructed so that they could follow the plot. The Polish audio introduction with its translation into English is included in Appendix 2.

\section{Results}

Analysis using SPSS showed a strong preference for the CRD. $67 \%$ of participants preferred it compared with $25 \%$ who preferred the STAD ( $8 \%$ reported no preference). Interestingly, a Chi-square test revealed a significant difference between genders. Male participants were significantly more likely to opt for the CRD compared with female participants $(p=.044)$. Mean scores for all measures are shown in Table 3. Preference by gender is shown in Table 4.

Table 3. Mean scores for presence and other measures, comparing standard and creative AD.

\begin{tabular}{llll}
\hline Measure & $\begin{array}{l}\text { Mean scores } \\
(\text { Standard AD })\end{array}$ & $\begin{array}{l}\text { Mean scores } \\
(\text { Creative AD) }\end{array}$ & Significance \\
\hline
\end{tabular}




\begin{tabular}{llll}
\hline Interest & 4.36 & 4.44 & .638 \\
Confusion & 1.72 & 3.46 & .045 \\
Spatial Presence & 3.79 & 3.93 & .048 \\
Engagement & 3.92 & 3.92 & .123 \\
Ecological Validity & 4.65 & 1.03 & .207 \\
Negative Effects & 1.03 & 1.00 & .324 \\
\hline
\end{tabular}

Table 4. AD style preference by gender.

\begin{tabular}{lllll}
\hline & Standard AD & Creative AD & Don't know & Total \\
\hline Male & 2 & 13 & 0 & $15(42 \%)$ \\
Female & 7 & 11 & 3 & $21(58 \%)$ \\
\hline Total & $9(25 \%)$ & $24(67 \%)$ & $3(8 \%)$ & 36 \\
\hline
\end{tabular}

Unlike in Fryer and Freeman's study, preference was not related to familiarity with AD (see Table 5).

Table 5. Preference by prior familiarity with AD.

\begin{tabular}{lllll}
\hline $\begin{array}{l}\text { I am used to listening to AD } \\
\text { (strength of agreement) }\end{array}$ & Standard AD & Creative AD & Don't know & Total \\
\hline 2 & 1 & 5 & 1 & $7(19 \%)$ \\
3 & 1 & 4 & 2 & $7(19 \%)$ \\
4 & 4 & 6 & 0 & $9(25 \%)$ \\
Strongly agree & 4 & 9 & 0 & $13(37 \%)$ \\
\hline Total & $9(25 \%)$ & $24(67 \%)$ & $3(8 \%)$ & 36 \\
\hline
\end{tabular}

The preference for the CRD is explained by the presence measures. Participants reported higher mean levels on all presence subscales (except negative effects) for the CRD style compared with that of the STAD. These differences were significantly higher 
for spatial presence $(p<.01)$. The CRD was deemed significantly less confusing $(M=$ 1.72) compared with the STAD $(M=3.46)(t=2.077, p=.045)$.

There was a significant negative correlation between preference for the CRD and how confusing people found it $(R=-.344, p=.04)$. A significant negative correlation was also found between the length of time a person's sight had 'been that way' and how confusing they found the CRD $(R=-.332, p=.05)$, suggesting that the CRD was less confusing to those who had lost their sight most recently. A Chi-square test between gender and how long a person's sight had 'been that way', was not significant ( $p=$ .422). Interestingly, in line with other studies (e.g. Cabeza-Caceres, 2013; Fryer \& Freeman, 2012a) enjoyment and comprehension were not related.

A one-way ANOVA comparing levels of presence between groups of different sight ability showed significant differences between groups for levels of spatial presence $(F=$ $3.629, p=.038)$ and ecological validity for the CRD $(F=4.887, p=.014)$. Levels of spatial presence were significantly lower for people with no light perception $(M=2.93)$ compared to those who could make out shapes of furniture in the room $(M=3.83)$. Similarly, for ecological validity, participants with no light perception reported lower levels $(M=4.36)$ than those who could tell by the light where the windows are $(M=$ 4.97). There was no significant difference in levels of any of the measures between 
those whose sight loss was congenital and those who had acquired sight loss. A Chisquare test showed no significant difference between sight ability and preference. Nor was there any difference between preference and whether or not a participant had seen the film before; the majority of participants (27/36) had not.

Levels of ecological validity for the CRD showed a significant correlation with the strength with which participants agreed that they would like to watch the whole film with this style of AD. There was no correlation between participants agreeing that they would like to watch the whole film with this style of $\mathrm{AD}$ for any of the presence measures for the STAD.

\section{Discussion}

The study shows a positive response to the CRD among blind and visually impaired people. Of 15 male participants, 13 stated a preference for the clips with the new AD style. Female votes were more balanced, with 11 opting for the creative version, seven for standard and three staying undecided. This might be due to Smarzowski's dark narrative style, full of ugliness and brutality, which may be less appealing to women. One blind man noted, 'The AD was succinct and to the point. The language was strong, but it suited the film. I enjoyed this "spicy" version a lot.' Another older blind man 
commented, 'There are many people struggling with alcoholism among the blind and they have the right to be given a realistic description and "see" this harrowing world of addiction. This AD could have been even gloomier!' A few female participants said that the CRD stirred their imagination and created a more believable atmosphere, but others were more negative, assessing it as too straightforward and realistic. A woman with low vision said, 'AD should be more objective, not that emotive.' Her visually impaired colleague argued, 'Better such $\mathrm{AD}$ than none, but this register is not the one I use in my everyday communication.' One blind woman pointed out that although the AD matched the film, she would not like to watch this type of production again, 'Smarzowski's style does not appeal to me. He is too brutal in his vision.'

Across the whole sample, the levels of spatial presence (I had a sense of 'being in the scenes') and ecological validity (The scenes seemed natural) for the CRD were higher for people with light perception. A likely explanation is that the CRD, thanks to the specific cinematic terminology and precise language expressions, allowed for more effective use of residual vision, and thus greater immersion in the clips presented.

Nevertheless, the CRD was new for all the participants and this may be why it seemed more confusing. People used to AD might not have expected to hear intensified vocabulary and this could have provoked certain disorientation. Besides, AD users do 
not usually encounter any cinematic terminology in the scripts and they might have found it too technical at times. But perhaps, as also shown in the study by Fryer and Freeman (2012b), it was easier to follow the film for participants with recent sight loss as their visual memory of cinematic effects was stronger. One participant, who is blind, commented, 'This new AD helped a lot. It provided many details without which I wouldn't be able to follow the film at all.' The correlation between ecological validity (The content seemed believable to me) for the CRD and the willingness of participants to watch the whole film audio described in this style shows that, presumably, the CRD made the story more realistic, and thus more in line with the director's artistic vision.

\section{Conclusion and further research}

This article presents a first analysis of the impact of AD style on the emotional experience of Polish B/VIP users. Two styles of AD - 'standard' and 'creative' - have been assessed. They have been applied to a naturalistic drama, a genre that has not been investigated in $\mathrm{AD}$ research before. From the conducted study, it is possible to conclude that the creative style of description had a significant effect on the emotional reception of the film by the audience. It obtained higher scores on all presence subscales and was assessed more favourably by participants compared to the standard AD style. 
Although this experiment is the first of its kind in the Polish context, it also has certain limitations. The sample was younger than average compared with the typical blind population, but plausibly reflective of the general audience for this director as his cinema is addressed to viewers with demanding tastes that have possibly encountered the problems shown on the screen (Mindykowski, 2012). Although the sample was larger compared to most $\mathrm{AD}$ reception studies, the findings may not translate to $\mathrm{AD}$ users from other countries. However, feedback from the participants confirmed that B/VIP people in Poland appreciate when the audio describer goes for more creative solutions in his text instead of strictly following the WYSIWYS maxim. Similarly to the studies by Fryer and Freeman (2012a) or Szarkowska and Wasylczyk (2014), the majority of users were positive about the new AD style. It prompted higher levels of presence for all participants, which confirms that not only visually attractive films, like Volver by Pedro Almodóvar (2006) (Szarkowska, 2013), but also the dark and naturalistic cinema of Wojciech Smarzowski work well with the CRD. Men liked the CRD more than women, but overall the scenes seemed more natural to all and made it a preferable option compared with the STAD. The novelty turned out to be confusing though, probably due to the unexpected use of emotional language or cinematic terminology that participants might not have been acquainted with. Nevertheless, participants with recent sight loss appeared to appreciate the CRD, as shown in the levels of their spatial presence and ecological validity. Although audio describers tend 
to 'protect' the audience, either from the cinematic technicalities or 'harsh realities of what is shown on screen' (Fryer, 2016), the AD text seems to be at its best when it is in tune with the image because, as such, it increases the chances of viewers having a more immersive experience.

As in the studies by Fryer and Freeman (2012b, 2013, 2014), presence measures proved effective for assessing the experience of the AD user. By focusing on reception, they seem to be a successful tool for verifying the reactions of those to whom AD is mostly dedicated. Due to political correctness, realistic images, violent scenes or sexual acts can be described in a factual manner (Chmiel \& Mazur, 2014), but they also tend to be 'silenced' by the describers (Fryer, 2016). Future research could explore AD for works containing such realistic elements and confront AD users with it to check whether they would opt for censored or non-censored versions of AD. It would also be interesting to compare their levels of presence after the screenings.

\section{Acknowledgements}

We would like to thank Wojciech Figiel, Robert Więckowski and Wojciech Maj for their kindness and support in finding volunteers for the study.

\section{Funding Acknowledgement}


This research was partially supported by the European project Hybrid Broadcast Broadband for All [FP7 CIP-ICT-PSP.2013.5.1 \# 621014]; by the project NEA (Nuevos Enfoques sobre Accesibilidad, New Approaches to Accessibility) [FFI2015-64038-P, MINECO/FEDER, UE]; and by the Catalan Government [2014SGR027].

\section{References}

Braun, S. (2008). Audio description research: state of the art and beyond. Translation Studies in the New Millennium, 6, 14-30.

Cabeza-Cáceres, C. (2013). Audiodescripció i recepció. Efecte de la velocitat de narració, l'entonació i l'explicitació en la comprensió fílmica. [Audio description and reception. The effect of speed of narration, intonation and explicitation in film comprehension]. (Unpublished doctoral dissertation). Universitat Autònoma de Barcelona, Spain.

Chmiel, A., \& Mazur, I. (2012). AD reception research: Some methodological considerations. In E. Perego (Ed.), Emerging topics in translation: Audio description (pp. 57-80). Trieste: EUT.

Chmiel, A., \& Mazur, I. (2014). Audiodeskrypcja [Audio description]. Poznań: Wydział Anglistyki UAM. Retrieved from http://hdl.handle.net/10593/12861 
Douglas, G., Corcoran, C., \& Pavey, S. (2006). Network 1000. Opinions and circumstances of visually impaired people in Great Britain. University of Birmingham. Retrieved from http://www.rnib.org.uk/Search/Pages/results.aspx?k=network\%201000\&s=All\%20Sites

Fels, D., Udo, J. P., Ting, P., Diamond, J. E., \& Diamond, J. I. (2006). Odd Job Jack described: a universal design approach to described video. Journal of Universal Access in the Information Society, 5, 73-81.

Fryer, L. (2016). An Introduction to Audio Description: A Practical Guide. Routledge, Oxford.

Fryer, L., \& Freeman, J. (2012a). Cinematic language and the description of film: Keeping AD users in the frame. Perspectives: Studies in Translatology, 21 (3), 412-426.

Fryer, L., \& Freeman, J. (2012b). Presence in those with and without sight: implications for virtual reality and audio description. Journal of Cybertherapy and Rehabilitation, 01/2012, 15 23.

Fryer, L., \& Freeman, J. (2013). Visual Impairment and Presence: Measuring the Effect of Audio Description. ACM International Conference Proceeding Series.

Fryer, L., \& Freeman, J. (2014). Can you feel what I'm saying? The impact of verbal information on emotion elicitation and presence in people with a visual impairment. In A. 
Felnhofer \& O.D. Kothgassner (Eds.), Challenging Presence: Proceedings of the 15th International Conference on Presence (pp. 99-107). Wien: facultas.wuv.

Fryer, L., \& Romero-Fresco, P. (2014). Audiointroductions. In A. Maszerowska, A. Matamala \& P. Orero (Eds.), Audio description: New Perspectives Illustrated (pp. 11-28). Amsterdam: John Benjamins.

Gross, J., \& Levenson, R. W. (1995). Emotion elicitation using films. Cognition and Emotion, 9, 87-108.

Hammick, J., \& Lee, M. (2014). Do shy people feel less communication apprehension online? The effects of virtual reality on the relationship between personality characteristics and communication outcomes. Computers In Human Behavior, 33302-310.

Künstler, I. (2010). Audiodeskrypcja - jak to się robi? [Audio description: how is it done?]. In I. Künstler, T. Raczek \& R. Więckowski (Eds.), Biała laska po kinowym ekranie (pp. 14-20). Warszawa: Wydawnictwo Polskiego Związku Niewidomych.

Lessiter, J., Freeman, J., Keogh, E., \& Davidoff, J. (2001). A cross-media presence questionnaire: The ITC Sense of Presence Inventory. Presence: Teleoperators, and Virtual Environments, 10 (3), 282-297. 
Lombard, M., \& Ditton, T. (1997). At the heart of it all: the concept of presence. Journal of Computer Mediated Communication, 3(2), 1-39.

Mindykowski, M. (2012). Wojciech Smarzowski. Retrieved from

http://www.polskatimes.pl/artykul/634755,wojciech-smarzowski-wywalam-moje-filmy-ztrzewi,id,t.html

Ofcom. (2008). Code on television access services. Retrieved from

http://stakeholders.ofcom.org.uk/broadcasting/broadcast-codes/tv-access-services

Rai, S., Greening, J., \& Leen, P. (2010). A comparative study of audio description guidelines prevalent in different countries. Retrieved from

http://www.rnib.org.uk/professionals/Documents/International_AD_Standards_comparative\%2

0study_2010.doc

Ramos, M. (2015). The emotional experience of films: does Audio Description make a difference? The Translator, 21 (1), 68-94.

Ramos Caro, M. (2016). Testing audio narration: the emotional impact of language in audio description. Perspectives: Studies in Translatology, 24, 1-29. 
Ramos Caro, M., \& Rojo López, A. (2014). ‘Feeling’ Audio Description: Exploring the Impact of AD on Emotional Response. Translation Spaces, 3, 133-150.

Romero-Fresco, P., \& Fryer, L. (2013). 'Could Audio Described Films benefit from Audio Introductions? A Reception Study with AD Users'. Journal of Visual Impairment and Blindness, July-August, 287-95.

Schmeidler, E., \& Kirchner, C. (2001). Adding Audio Description: Does It Make a Difference? Journal of Visual Impairment and Blindness, 95:4, 198-212.

Slater, M., \& Usoh, M. (1993). Representations systems, perceptual position, and presence in immersive virtual environments. Presence, 2(3), 221-233.

Snyder, J. (2008). Audio description: The visual made verbal. In J. Díaz Cintas (Ed.), The Didactics of Audiovisual Translation (pp. 191-198). Amsterdam/Philadelphia: John Benjamins.

Styan, J. L. (2002). Modern Drama in Theory and Practice: Volume 1, Realism and Naturalism. Cambridge: Cambridge University Press.

Szarkowska, A. (2013). Auteur Description: From the Director's Creative Vision to Audio Description. Journal of Visual Impairment \& Blindness, September-October, 383-387. 
Szarkowska, A., \& Jankowska, A. (2015). Audio describing foreign films. Journal of Specialised Translation, 23, 243-269.

Szarkowska, A., \& Wasylczyk, P. (2014). Audiodeskrypcja autorska [Auteur description]. Przektadaniec, 28, 48-62.

Taylor, C. (2014). Textual cohesion. In A. Maszerowska, A. Matamala \& P. Orero (Eds.), Audio description: New Perspectives Illustrated (pp. 41-60). Amsterdam: John Benjamins.

Udo, J. P., Acevedo, B., \& Fels, D. (2010). Horatio audio-describes Shakespeare's Hamlet. Blind and low-vision theatre-goers evaluate an unconventional audio description strategy. Bristish Journal of Visual Impairment, 28 (2), 139-156.

Udo, J. P., \& Fels, D. (2009). 'Suit the Action to the Word, the Word to the Action': An Unconventional Approach to Describing Shakespeare's Hamlet. Journal of Visual Impairment and Blindness, 103 (3), 178-183.

Walczak, A. (in press). Creative Description: Audio Describing Artistic Films. Journal of Visual Impairment and Blindness.

Walczak, A., \& Rubaj, M. (2014). Audiodeskrypcja na lekcji historii, biologii i fizyki w klasie uczniów z dysfunkcją wzroku [Audio Description in History, Biology and Physics Classes for 
Visually Impaired Learners]. Przektadaniec, 28, 63-79.

Appendix 1. Scale on light perception, the ability to recognize friends and to read.

1. Which of these best describes your sight with glasses or contact lenses if you normally use them?
A: I have no light perception
B: I can tell by the light where the windows are
C: I can see the shapes of furniture in the room

2. I can recognise a friend by sight alone if...

D: I'm close to their face

E: I'm at arms' length away

F: I'm on the other side of the room

G: I'm on the other side of the street

3. I can...

$\mathrm{H}$ : Read a newspaper headline

I: Read a large print book

$\mathrm{J}$ : Read ordinary newsprint 
Appendix 2. The Polish audio introduction to The Mighty Angel with its translation into English.

[PL]

Rytm filmu jest hipnotyczny. Szybkie ujęcia, nielogiczny układ scen, ciągłe przebitki, retrospekcje. Dzień miesza się z nocą, zaciera się granica między jawą a snem, bohaterowie pogrążają się w alkoholowych odmętach.

\section{$[\mathrm{EN}]$}

The rhythm of the film is hypnotic. Fast shots, illogical scene composition and continuous flashbacks. Day becomes mixed with night, the border between reality and dreams becomes blurred, and the protagonists are plunged into an alcoholic vortex. 